\title{
Aunuse kubermangu talurahva pühade süsteem 19. sajandi lõpul ja 20. sajandi alguses
}

\author{
Irina Vinokurova
}

Teesid: Esimesi asju, millega uurija kokku puutub, uurides erinevaid pühasid mingil kindlal territooriumil, on nende pühade süstematiseerimine ja klassifitseerimine. Käesolev artikkel püüab vastata küsimusele, millised peamised pühade kategooriad olid Aunuse kubermangu külades levinud 19. sajandi lõpus ja 20. sajandi alguses, mil pärimuskultuur püsis üsna stabiilsena.

Märksõnad: Aunuse kubermang, pärimuskultuur, talurahva pühad, vepsa

Vaadeldava ajavahemiku traditsiooniliste pühade süsteemi rekonstrueerimisel Aunuse kubermangus esineb teatud raskusi. Üks neist on allikate seisukord. Neis ei ole esindatud kaugeltki kõik asustuspunktid ja seal käibel olnud pühad, pealegi on paljud asulad praeguseks kadunud või on vahetunud nende nimi. Teine probleem on etniline Aunuse kubermangu territooriumi paljurahvuselisus, mis ei saanud mõjutamata jätta ka pühade süsteemi. Ammustest aegadest on siin elanud vepslased, karjalased ja venelased.

Esimese ülevenemaalise rahvaloenduse andmeil 1897. aastal pidas $78,2 \%$ Aunuse kubermangu elanikkonnast oma emakeeleks vene, $16,3 \%$ karjala, $4,4 \%$ vepsa (tšuudi), $0,7 \%$ soome ja $0,4 \%$ mõnd muud keelt (juudi, poola, mustlas-, saksa, ukraina, tatari, valgevene vm keel). Peaaegu kõik Aunuse kubermangus elanud karjalased (99,8\%) 
elasid kubermangu lääneosas - Aunuse, Petroskoi ja Poventsa kreisis ${ }^{1}$. Kubermangu idaosas (Puudoži, Kargopoli ja Võtegra kreis) elasid neist üksikud, aga Lodeinoje Pole (Lotinapelto) kreisis pisut üle saja inimese. Vepslased elasid Lodeinoje Pole (vepsa Püud) kreisi Vidla, Ošta, Podporožje (vepsa Kośkenaluine), Šapša ja Šimǵäŕi vallas ja Petroskoi kreisi Šeltozero-Berežni ("Ranniku-Šoutaŕve") vallas. Võtegra, Poventsa ja Aunuse kreisis oli neid vaid kümme inimest. Venelased olid hajutatud kogu kubermangu territooriumile, absoluutse enamuse moodustasid nad Puudoži, Kargopoli, Võtegra, Lodeinoje Pole ja Petroskoi kreisis (Pokrovskaja 1974: 102, Venemaa TA arhiiv f 135, op 2, nr 627).

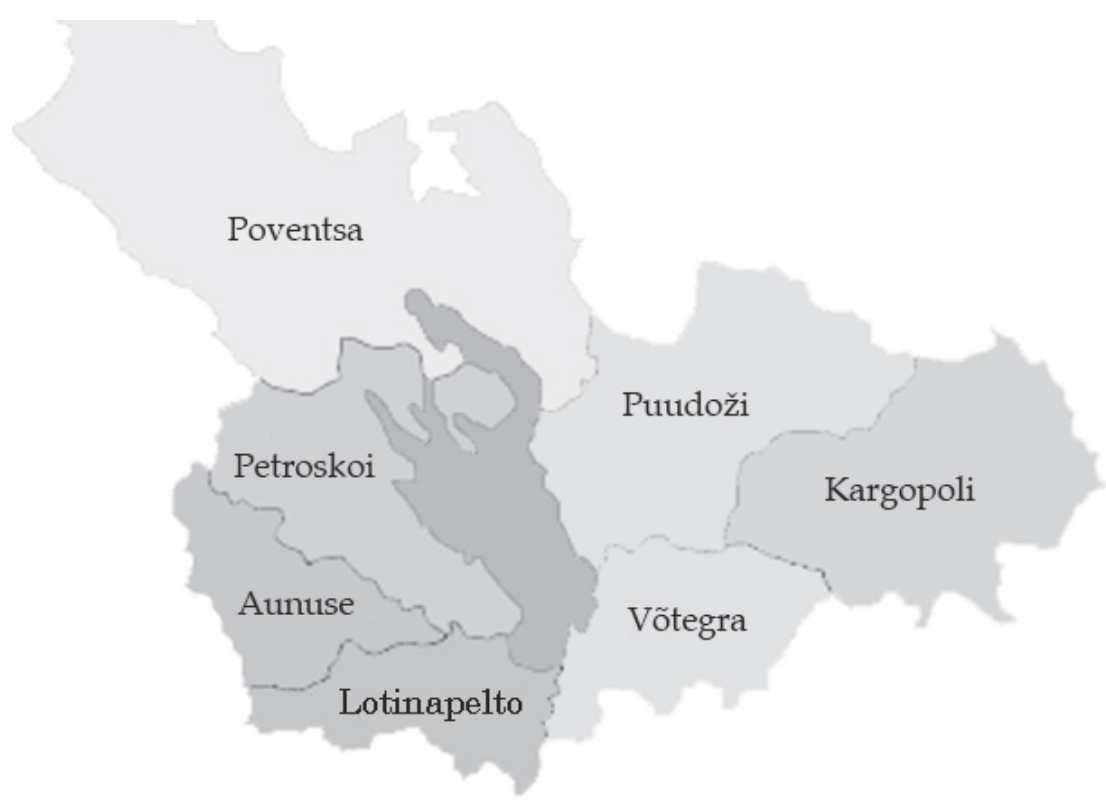

Aunuse kubermangu kaart.

Nimetatud asjaolude tõttu ei pretendeeri käesolev artikkel probleemi lõplikule lahendamisele. Siin visandatakse Aunuse kubermangu kõigile rahvastele ühise kogukondlike pühade klassifikatsiooni kõige üldisem skeem, mis edasisel teemasse süvenemisel täpsustub ja täieneb. 
Nagu eeldatud, tuleb süstematiseerimist alustada mõiste "püha" määratlemisest. Uuritaval ajajärgul kasutasid Aunuse kubermangus nii venelased kui ka läänemeresoome rahvad vene sõna праздник ('püha' või 'pidu') mitmete perioodiliste kogukondlike pidustuste tähistamiseks; vrd põhjakarjala pruaznikka (Repoĺa), proaznikka (Poadene); livvi proazńiekku (Vieljärvi), priaznikko (Konduši); lüüdi pruasniekke (Pyhärv), pruaznik (Kuujärvi); põhja-, kesk-ja lõunavepsa prazńik (SOSDKVSJ 2007: 1265). Vene sõna праздник tuleb vanaslaavi sõnast $n p a 3 \partial b$, mis tähendas puhkust, tegevusetust, laiskust; seetõttu tähendab ka omadussõna праздньıй laiska, tühja, kasutut, tööga mittetegelevat jne (Beloussov 1974: 6). Selline tõlgendus peegeldab ainult ühte pühade külge, mis teda argisest eristab - töötegemise puudumist. Just sellele traditsioonilisele pühade tähtsale tunnusele viitasid ka informandid, rõhutades, et pühade ajal töötamist peeti suureks patuks. Neid etnograafilisi fakte kinnitavad andmed vepsa ja karjala leksikast: vepsa sõnal güudai (juudei) on lisaks tähendustele "tühi", "vaba" ka ülekantud tähendus "pidulik", "tegevusest vaba", livvikarjala murdes tähendab jowdavus mittehõivatust, jõudeolekut, tegevusetust (Zaitseva \& Mullonen 1972; SKJ 1990: 104). Samas osutavad keelelised andmed ka sellele, et läänemeresoome rahvastel oli vanasti pühade tähistamiseks oma sõna - pühä ( $p y h \ddot{a})$. Soomlastel tähendab pyhä - 1) püha; pidupäeva; pühapäeva; 2) püha, pühalikku, pühitsetut; pyhäpäivä - pidulikku päeva, pühapäeva (FRS 1975: 496). Karjalastel ja vepslastel on sõna pühä säilinud tähenduses "pühalik" ja "paast"; pühäpäivü (livvi), pühäpäiv (lüüdi, põhja- ja lõunavepsa) pühapäev (SOSDKVSJ 2007: 328). Need tähendused rõhutavad mitte üksnes pühadeaegseid tegevuskeelde ja -piiranguid, vaid ka püha sakraalset sisu. Paljudel maailma rahvastel on levinud pühasid tähistavaid nimetusi, mille semantiline tähendus sisaldab sakraalsuse ideed (vrd vn святки, ukr свято, pl swieto, srb-horv свечаник jne sõnast svet 'püha, sakraalne'; ingl holiday sõnast holy 'püha'; mittehõivatust, tegevusetust (vrd ukr неділя) (Beloussov 1974: 7; Toporov 1997: 329).

Iga püha aluseks on mingi oluline sündmus kogukonna või üksikperekonna elus; muutused kosmilis-looduslikus ilmas ja tähenduslik päev seda kehastava(te) jumalus(t)e elus, õnnestunud jaht, viljakoristuse lõpp, karja kidumise või epideemia ärahoidmine, pühakoja ehitamine, õigeusu pühaku mälestuspäev, võit lahingus või sõjas jms. Juba nende juhtude loetelu siin annab tunnistust, et pühade klassifitseerimine on üsna keeruline. Tuntud Poola sotsioloog Kazimierz Żygulski nimetab 
pühade korrastuslike peamiste kriteeriumite seas nende ruumilist mastaapsust ja aega. Ta kirjutab: "Pühade, nagu ka inimkultuuri teiste ilmingute levikut võib kujutada ette kaardina. Me leiame sellel kohalikke, paikseid pühasid, mille levik on piiratud, piirkondlikke, rahvuslikke, riiklikke ja lõpuks ka rahvusvahelisi pühasid. Lisaks kaardile, mis annab meile ettekujutuse pühade ruumilisest levikust, võib koostada ka ajaloolisi kaarte, mis taasloovad pildi ühe või teise möödunud ajajärgu pühadest. Sellised kaardid iseloomustavad ilmekalt pühade ruumilist dünaamikat, pühade ümberpaigutusi, mis on sageli tingitud religioossete kombetalituste ümberpaigutustest, aga tulenevad ka majanduslikest, seisuslikest ja poliitilistest muutustest" (Żygulski 1985: 62-63). Need kriteeriumid tunduvad üsna õnnestunud ja põhjendatud. Neid on arvestatud ja nendega katsetatud Aunuse kubermangu Äänisjärve piirkonna vepslaste traditsiooniliste pühade süstematiseerimisel (Vinokurova 1996: 21). Kujutades pühade levikut kindla geograafilise piirkonna kaardil, saab eristada järgmisi rühmi:

1) üleüldised pühad, mis hõlmavad kogu põhjavepsa areaali;

2) ühe põhjavepsa külastu pühad (pühakoja- või patrooni- ning tõotuspühad - vene keeles vastavalt храмовые, престольные, заветные - toim). Selle rühma puhul tuleb võtta arvesse vepslaste Äänisjärve äärse asustuse eripärasid. Selles piirkonnas on levinud külastu-tüüpi asustus. Külastu tähendab üksteise lähedal asuvate külade rühma. See kandis ühist nimetust, mis tavaliselt langes kokku geograafilise objekti (järv, jõgi, mägi) nimega, mille kõrval küla asus. Samal ajal oli igal külastusse kuuluval külal ka oma nimi. Näiteks ühendas Šoutaŕve külastu umbes 15 erinimelist küla. Külastu levinuim tüüp oli kirikuküla (pogost). Pogost, mille piirid langesid tavaliselt kokku külakogukonna piiridega, kujutas endast 19. sajandil ja 20. sajandi alguses administratiivset ja religioosset keskust, mis koondas enda ümber rühma külasid. Pogostis asus üks või kaks kirikut ja kalmistu, mis ühendas kogukonna koguduseks (vene nрuxod, vrd ka eesti kirikukihelkond - toim) religioosseks tervikuks; samuti kaubanduslikud, aga mõnikord ka administratiivasutused (vallavalitsus) (Pimenov 1964: 4-7). Pärast 1861. aasta reformi langesid kirikukoguduse ja valla piirid sageli kokku (Russkie 1997: 603). Sellist asustuse maastikul grupeerumist arvesse võttes saame kolmanda pühade rühma: 
3) ühe põhjavepsa küla pühad (tšasovenskie ${ }^{2}$, tõotuspühad). Iga küla koosneb seejuures mõnest majapidamisest. Selle põhjal saab eristada veel:

4) põhjavepsa ühe pere pühad.

Kui vaadata neid pühasid ajalises lõikes, on meie ees rahvakalendri, kiriklikud ja ilmalikku päritolu pühad. Vanimad on rahvakalendri pühad, mida tähistati perioodiliselt ja mis olid seotud samal ajal asetleidvate aastaajaliste muutustega looduses, samuti inimeste majandustegevuse tähtsamate etappidega. Need pühad võisid olla ühised kogu Äänisjärve piirkonnas (näiteks mitmepäevane vepsa püha sünduma, mida tähistati päeva pikenemise puhul, või maitpühäpanom - talve lõppu tähistav vastlanädal), aga ka kitsamalt kohalikud pühad. Pidupäevade kombestikulise päritolu teooria pooldajad oletavad, et aja jooksul on suurem osa inimese majandustegevust ja igapäevaelu saatnud elutsükliga seotud kommetest järk-järgult sellest eemaldunud ja neid on hakatud tähistama erilisematel, enam tähenduslikel aastatsükli päevadel, mis on vabad tööst - pühadel. Paljude maailma rahvaste kalendrite põhjal võisid algselt sellisteks päevadeks olla töökeeluga nädalapäevad - kuufaasidega seotud pühapäevad, pööripäevad jt. Aja jooksul rikastusid iidsed pühad kultuurilises läbikäimises, teisenesid uuteks kommeteks, mängudeks ja muudeks meelelahutusteks. Hilisemad olid kiriklikku päritolu pühad. 17. sajandil, Peeter I ajal ilmusid Venemaa rahvaste kalendrisse ilmalikud pühad (uue aasta tähistamiseks 31 . detsembri öö vastu 1 . jaanuari, keiserliku perekonna liikmete nimepäevad jne). Rahvakalendri pühasid püüti siduda kristlike tähtpäevadega, sulandada neid kiriklikku ja ilmalikku päritolu pühadega, mõnikord sulandusidki need lahutamatult. See protsess kajastub vepslastel mõnede pühade topeltnimetustes: üks on kiriklikku päritolu, teine rahvapärane, kusjuures viimane oli nii mõnelgi juhul seotud pühapäevadega. Näiteks suvine Kaasani Jumalaema ikooni päev (8. juuli) $)^{3}$ - sįrpühäpäi (juustupühapäev) Leningradi oblasti Boksitogorski rajooni Sodjäŕve külas; "soe nigul" (pärast eeliapäeva) - ristpühäpei (püha ristimispäev) Vologda oblasti Võtegra rajooni Šimǵäŕe külas; Jumalaema uinumise püha (15. august) - emaganpäi (perenaisepäev).

Kahtlemata oli Aunuse kubermangu karjalastel ja venelastel, kel Vene riigis oli vepslastega sarnane administratiivne ja religioosne elukorraldus, pikaajalised omavahelised etnokultuurilised kontaktid 
ning enamvähem sama tüüpi asustus, levinud analoogne pühadesüsteem, mille aluseks olid ruumilised ja ajalised kriteeriumid. Mõningad etniliste traditsioonide ja lokaalsete erijoontega seotud erinevused ei puudutanud pühadesüsteemi tervikuna, vaid pühade liigilist külge, nende pidamise vormi.

Sel moel võib Aunuse kubermangu talurahva kogukondlikud pühad jagada kahte suurde rühma: üldised ja kohalikud. Kohalike pidustuste hulgas eristusid suurema asustusüksuse (pogost, kogudus, vald) ja küla peod. Nende hulka kuulusid patroonipühad, külapühade hulka kabelipühad (vene часовеннье). Järjekindlalt tähistati ka tõotuspühasid, mille tähtsus võis piirduda külastu, küladerühma või ühe külaga. Aunuse kubermangu mõnede külastute pühadesüsteemi ere näide, mis on hämmastanud koduloolasi ja uurijaid, olid looma ohverdamise ja/ või õllejootudega seotud patrooni- ja tõotuspühad.

Kõigil pühadel olid nii üldised kui ka spetsiifilised komponendid. Religioossete pühade struktuur oli peaaegu ühesugune. Üldjuhul koosnes see liturgiast, ristikäigust, söömaajast, pidustusest ja laadast. Omapära lisasid pühale tema aluseks olevad sündmused, tähistamise aeg ja kombed, sealhulgas ka need, mis olid seotud inimese majandustegevuse või elutsükliga, ning lõbustused. Näiteks uue aastaga seostuva Kristuse sünni (25. detsember) tähistamisele olid iseloomulikud kombed ja talitused, mille aluseks oli esimese päeva maagia, samuti noorte kombed, mille eesmärk oli kaasa valimine paastudevahelisel perioodil kui massilisel pulmade korraldamise ajal. Kõiki suviseid pühasid ühendas looduse õitsengu idee. Suvistepüha (troitsa) eripära oli majade, kirikute ja kalmude kaunistamine seest ja väljast kaseokste või neist punutud võrudega.

\section{Üldised pühad}

Üldtähistatavad pühad, mida tähistas kogu Aunuse kubermang, olid samad nagu kogu Venemaal. Enne revolutsiooni oli Venemaal üle 30 riikliku püha. Iganädalane pidulikum päev oli pühapäev. Kõigi õigeusklike rahvaste peamiseks pühaks, "kõigi pühade pühaks" peeti ülestõusmispühi. Pidupäevadeks peeti Venemaal suurt neljapäeva ja reedet ning vaikset laupäeva, samuti kogu ülestõusmisnädalat. Riiklikud pühad olid ka kõik suured pühad - kaksteist suurpüha pärast lihavõtteid ja viis muud, välja arvatud Ristija Johannese sünnipäev 
(24. juuni) (Polištšuk 1997: 584). Kaheteistkümne suurpüha hulka kuulus aastas kaksteist Jeesus Kristuse ja Jumalaemaga seotud püha: liikumatud pühad Kristuse sünnipäev (25. detsember), Issanda ilmumise suurpüha (6. jaanuar), Issanda templisseviimise püha (2. veebruar), Neitsi Maarja rõõmukuulutamise päev (25. märts), Issandamuutmise päev (6. august), Jumalaema uinumise päev (15. august), Neitsi Maarja sündimise päev (8. september), ristiülendamise päev (14. september), Neitsi Maarja templisseviimise püha (21. november) ning liikuvad pühad - Issanda Jeruusalemma minemise päev (viimane ülestõusmispühade eelne pühapäev), Issanda taevasseminemise püha (40. päev pärast ülestõusmist), Kolmainu püha (troitsa, 50. päev pärast ülestõusmist). Suurteks, kaheteistkümne suurpüha hulka mittekuuluvaks pühaks loeti ka viis evangeeliumisündmusi märkivat püha: Issanda ümberlõikamise päev (1. jaanuar), Ristija Johannese sünnipäev (24. juuni), pühade apostlite Peetri ja Pauli päev (29. juuni), Ristija Johannese pea maharaiumise päev (29. august), Neitsi Maarja kaitse ja eestpalve püha (1. oktoober). Riiklikeks pühadeks olid arvatud ka Nikolai Imetegija päev (9. mai), vürst Aleksander Nevski säilmete toomise päev (30. august), apostel ja evangelist Johannese päev (26. september), Kaasani Jumalaema ikooni päev (22. oktoober). Tööst vabadeks päevadeks olid kuulutatud ka vastlanädala reede ja laupäev.

Ilmalikest pühadest peeti riiklikeks uut aastat ja nn keiserlikke päevi (иарские дни). Keiserlikeks päevadeks nimetati Venemaal igaaastaseid keiserliku perekonna liikmete auks peetavaid pidupäevi. Need jagunesid eriti pidulikeks ja pidulikeks. Esimeste hulka kuulusid valitseva monarhi troonileastumise päev; kroonimispäev; imperaatori, valitsevate ja lesktsarinnade, tsarevitši ja tsarejevna sünni- ja nimepäevad. Pidulikeks keiserlikeks päevadeks peeti kõigi teiste tsaariperekonna liikmete nime- ja sünnipäevi (http://ricolor.org/ history/mn/romanov/king_days). Keiserlikud päevad, mida linnades peeti uhkelt, piirdusid külades kirikuteenistusel käimisega. Leidub vähest teavet ka selle kohta, et tsaari nimepäevadel ei maetud põhjavepsa külades kunagi surnuid (Perttola, SKS, № 641). See ja teised näited tõendavad, et kõrgemate kiriku- ja riigivõimude kehtestatud ametlik pühadehierarhia ei langenud reaalses elus alati kokku rahva suhtumisega nendesse. Sageli mängis rahvalikku päritolu kohalik püha (nt tõotuspüha, nagu ka allpool näha) elanikkonna elus suuremat rolli kui ametlik püha (Žigulski 1985: 65). 


\section{Kohalikud pühad}

1. Suurema asustusüksuse (pogosti, koguduse, valla) pühad Aunuse kubermangus. Siintoodud teise pühade rühma kuulusid eelkõige pühakoja ehk patroonipühad. Patroonipühi korraldati pühaku auks või püha ajaloosündmuse tähistamiseks, mille järgi oli nimetatud kohalik kirik või selle altarid. Patroonipühad olid enam au sees. Nii mõnelgi juhul langesid nad kokku üldiste pühadega, mis lisas neile suuremat pidulikkust ja hoogu. Vanasti oli igal Aunuse kubermangu külastul oma kirik, sageli ka kaks mitme altariga, talvine kivist ja suvine puust, ning aastas tähistati patroonipüha kaks, aga mõnikord ka kolm-neli korda. Näiteks olid karjala asulates pühakoja pühad Seämärvis Jumalaema ja Neitsi Maarja taevasseminemise päev (emänpäivü, uspeńu), Issanda ristimine (vieristü), Videles - Neitsi Maarja kaitse ja eestpalve püha (pokrov), apostlite Peetri ja Pauli mälestuspäev (pedrunpäivü) jne (Konkka 2008: 341; Sarmela 1969: 78-79). Vepsa külastutes tähistati Šokšas nelja patroonipüha - suvine ja talvine nigulapäev (mikulan päiv, 9. mail ja 6. detsembril), pühade apostlite Peetri ja Pauli päev (pedrum päiv), Neitsi Maarja kaitse ja eestpalve püha (pokrov); Šoutaŕves kolme: kevadine ja talvine Suurkannataja ja võidutooja Püha Jüri päev (jürgin päiv) (23. aprillil ja 26. novembril), Issandamuutmine (spasan päiv) jne (Vinokurova 1996: 40, 43). Važenvaras oli kaks patroonipüha (taevaminemispüha ja Neitsi Maarja kaitse ja eestpalve püha) (Sarmela 1969: 79); Derevjanski vallas kolm (Nikolai Imetegija püha, Issanda templisseviimise püha, Neitsi Maarja kaitse ja eestpalve püha); Kansaniemi vallas (Vodlajärvi) tähistati kolme pühakoja tähtpäeva - prohvet Eelia päev (20. juulil), Jumalaema taevasseminemise päev, püha Vassili Suure päev (vassilipäev 1. jaanuaril), Kuganavolokis kahte: Neitsi Maarja sündmise päev (8. septembril), pühade apostlite Peetri ja Pauli mälestuspäev (peetripäev) (K. P 1883: 646; Loginov 2005: 108).

Erinevalt teistest traditsioonilistest pühadest olid patroonipühad "külalistega", see tähendab, et nende peamise komponendi moodustasid naaberasulate elanike vastastikused külastused. Äänisjärve vepslaste alal ja Seesjärvi karjalaste juures võeti patroonipühadel külalisi vastu rangelt suguluse alusel. 16. sajandist on säilinud dokumendid, kus on mainitud hõimupidustusi, mis on levinud kogu Karjala territooriumil. Nende eripära oli suguvõssa mittekuuluvate kutsumata külaliste tuleku keeld. Need faktid viitavad sellele, et pühakoja pidustused 
imasid endasse läänemeresoome rahvaste sugulusprintsiibil põhinenud varasemate suguvõsapidustuste korraldusliku külje. Aja jooksul need põhimõtted lõdvenesid. Nii käisid 19. ja 20. sajandi vahetusel Siämärvi äärsed livvikud "pühade ajal sugulaste juures külas, kuid küllatulevad sugulased võisid võtta kaasa naabreid, naabrid omakorda oma tuttavaid. Kõiki võeti vastu, neid söödeti, joodeti ja anti öömaja. Kuni kolm päeva võisid külas viibida nii tuttavad kui võõrad" (Konkka 2008: 334-335). Erandi moodustasid alati kerjused, kes pühade ajal külla sattusid. Neile pakuti külakosti, mõnikord pandi istuma pidulauda. Selle kombe aluseks oli iidne ettekujutus vaestest kui surnute asendajatest. Arvati, et lahkunud kuulusid endiselt antud suguvõssa ja kohtusid omastega peo ajal. Erinevalt vepslastest ja karjalastest ei piirdunud mõnes vene piirkonnas kirikupühade külalistering üksnes sugulastega. Näiteks Pomorjes käisid patroonipühadel pidutsejate juures "kõik elanikud, mitte tingimata sugulased" (Bernštam 2009: 174-175).

Pühakoja peol oli kindel korraldus. Harilikult kestis see kaks-kolm päeva. Külalised saabusid juba pidustuste eelõhtul ja seadsid end sugulaste juures sisse. Pidustuste esimene päev nägi välja järgmiselt: hommikusöök (mõnikord jäi ka ära), liturgia külastamine kirikus, surnute mälestamine kiriku juures asuval kalmistul, ristikäik, lõunasöök, külaskäimine, vabaõhupidu (guljanje) vaheaegadega õhtuooteks ja õhtusöögiks, ka noorte koosviibimised, kui pidu sattus Neitsi Maarja kaitse ja eestpalvepüha ning suure paastu vahele.

Pidusöök patroonipühade ajal ei olnud kogu Aunuse kubermangus ühesugune. Piirkondlikud erinevused olid seotud etniliste ja elatuslike traditsioonidega, seostusid aastaaja, paastu või kehvema perioodiga, perekonna suurusega. Külluslik peolõuna koosnes mitmest roast, mida serveeriti kindlas järjekorras. Seesjärvi karjalastel, põhjavepslastel ja Äänise-tagustel venelastel oli roogade serveerimine üldjoontes sarnane. Kindlasti kuulus sinna esimese roana kalapirukas, seejärel mingi teine küpsetis, edasi supp (kalast või lihast), väikesteks tükkideks lõigatud supiliha või kala, mida serveeriti eraldi. Pärast seda võis täheldada serveeritavates roogades, nende hulgas ja nimetustes teatavaid lahknevusi. Seesjärvi karjalastel näiteks anti pärast liha piima, karjala pirukaid ja kosovikuks kutsutud pirukat (kosovikka), mis koosnes kahe kartuli- või rukkijahutaignast kaku vahele pandud odrajahust pannkoogist pudruga (Nikolskaja 1981: 143). Äänisjärveäärsetel vepslastel järgnes lihale munaroog (munapirg) või kartulivorm 
(rädovik) rõõsa ja hapupiimaga (Vinokurova 1996: 47). Pidusöögi lõpu tähistajaks oli igal pool kissell.

Aunuse kubermangu naaberpiirkondade allikad mainivad, et 1641. aastal koguti Põhja-Karjalas Pälkjärvi külastus prohvet Eelia päeva ja Salmis (Laadoga-Karjala) Nikolai päeva pühitsemiseks "igast majapidamisest pool vilja õlle jaoks, mida igaüks võis peo ajal juua nii palju kui soovis". Ühise õlle valmistamine kokkukogutud vahenditest ja selle koos pruukimine oli 1695. aastal kombeks ka LaadogaKarjalas Suojärvis ja Kornijärvis nädal enne Ristija Johannese sünnipäeva (Sarmela 1969: 32). Need faktid kinnitavad, et 17. sajandil toimusid mõnedes Karjala külades, samuti Novgorodi ja Vologda kubermangu venelastel, isuritel, vadjalastel, Kapša ja lõunavepslastel patroonipühadega koos õllejoodud (Vinokurova 1994: 35-36). Seda on üles märgitud ka Aunuse kubermangu Kargopoli kreisi Fatjanovo valla vene küladest (Kulikovski 1895: 5-6). Aunuse kubermangu läänepoolsetes valdades ei olnud uuritaval ajal õlletegemine pühakoja pühadel kuigi levinud. Näiteks R. Nikolskaja andmetel Seesjärvi karjalased "kasutasid alkohoolseid jooke väga vähe: ei pruulinud õlut ega teinud meskit" (Nikolskaja 1981: 144). Sama võib öelda põhjavepslaste ja Äänise-taguste asukate kohta (Vinokurova 1996; Loginov 1993: 130). T. Bernštam on täheldanud samuti õlle rolli vähenemist suurtel pidudel ja nimetuse “õlle-" kadumist mõnedes põhjavene piirkondades (näiteks Arhangelski kreisis), mis tema arvates on seotud vilja vähesusega neis piirkondades (Bernštam 1988: 217).

Pärast pidulikku lõunat algas rahvapidu (guljanje), mis sisaldas pidulikult riietatud inimeste, peamiselt noormeeste ja neidude korrapärast ringiliikumist teiste külaelanike ees eraldi viirgudena üksteise järel laulude ja lõõtsamängu saatel; aga ka lõbutsemist mängude ja tantsudega. G. Kulikovski on kirjeldanud guljanjega kaasnevaid tantse Kuzarandas pühakoja pühal Ristija Johannese sünnipäeval: "Küla taha mäejalamile kogunesid noored, kaugemalt paistis kaks rühma: üks tume, ühetooniline - need olid kavalerid, teine kirev, peamiselt punastes, valgetes ja kollastes toonides - need on tüdrukud, keskel see kõik seguneb ja justkui liigub. Ent tuleme lähemale. Liikumine on tõepoolest olemas, kuid äärmiselt aeglane: tantsitakse "ringi". See tants on järgmine: nagu juba öeldud, seisavad kaks rühma eraldi, aga kui kõlab lõõtsa aeglane heli, astub keskele kavaler ja, kutsunud enda juurde tütarlapse, võtab tal käest ning asub aeglaselt ringjoones liikuma; tantsu võetud tüdruk kutsub enda juurde poisi, esimesena ette 
astunud kavaler võtab teise tüdruku, see kutsub jälle noormehe, aga teisest otsast lisandub jälle tütarlaps; kett liigub ja kasvab mõlemast otsast, vahelduvad noormees, neiu, noormees, neiu, noormees jne, alguses on ringis üks paar, siis kaks, kolm, neli, viis paari ja rohkem, kõik liiguvad ainult ühes suunas. Tants on äärmiselt ühekülgne, tema ühekülgsus on veelgi tuntavam, kui Aunuse tantsu asendab Prantsuse kadrill oma kuue figuuriga" (Kulikovski 1888: 515-516).

Karjalaste peokultuuris oli tuntud noorte pidutsemisviis, mille silmatorkavaim joon oli piduliku rongkäigu ja mängude ühitamine. Seda mängulist rongkäiku kutsuti pitkäkisa (Põhja-Karjalas), pitkykiza (livvi, "pikk mäng"), puarakiža (Seesjärvis, "paarismäng”), pitkä paara (laadogakarjala, "pikk paar"). See käis nii, et noormees, valinud endale jalutuspaariliseks neiu, juhtis ta kättpidi või tõmmates rätikust, mille teisest otsast hoidis neiu, kaugele, kusagile põllule või metsa. Seal istusid nad sobivas kohas maha ja ajasid juttu. Siämärvi külast talletatud teate kohaselt "käidi "pika mängu" ajal mäel ja põldudel. Mäele minnes istuti seal paaridena kadakaste küngaste taga" (Konkka 2008: 335). Kui vastastikust sümpaatiat mängu ajal ei tekkinud, naasis paar peagi mänguplatsile. Noormees kutsus "pikale" jalutuskäigule uue väljavalitu, eelmisel neiul tekkis samal ajal uus partner (Surhasko 1977: 51). Laadogakarjalastel kirjeldati pitkä paara ("pika paari") tüdrukute valimist järgmiselt: "Niinimetatud pitkä paara läbib rahvast täis peopaika. Esimestena lähevad paaris üksteisel käest kinni hoides neiud, püüdes pilke värvikate riietega, üks kirkam kui teine. Noormehed jälgivad alguses ujedalt lähenevaid tüdrukuid, kuid leides meelepärase, ühinevad nendega ja moodustuvad uued paarid - poisid piigadega. Akordion mängib kõvasti. Kõige ilusamad ja samal ajal kõige rikkamad käivad alati esimeste paaridena. Vanad inimesed seisavad ümberringi ja jälgivad noori (Sarmela 1969: 73).

Guljanjed jagunesid sügis-talvisteks ja kevad-suvisteks, nende pikkus sõltus püha suurusest ja tähtsusest. Guljanjeid eristas lisaks ajale ka läbiviimise koht. Sügis-talvised hõlmasid väiksema territooriumi kui kevad-suvised. Laadoga-äärsetel karjalastel oli sügis-talviste guljanjete jaoks suurepärane koht jõe- või järvejää, millel noormehed jalutasid tüdrukutega paaris või sõitsid hobustega (Sarmela 1969: 71). Kõige sagedamini leidis sügis-talvine guljanje aset küla peatänaval. Kevad-suvisel ajal laienes ka guljanje ala: need toimusid mitte üksnes külatänavatel, kiriku- ja kabeliplatsidel, vaid ka küla taga asuvates väljakujunenud kohtades - sillal, teel, nurmel, mäel, veekogu kaldal jne. Pidutsemispaikadel olid erilised nimetused. 
Ammusest ajast saatis palju rahvast kohale toovaid pühakoja pidustusi kauplemine. Ringijalutava rahva tähelepanu objektiks olid ka küla peatänavale või kiriku juurde platsile ülesseatud kaubarivid. "Pidupäeva varahommikul saabuvad kaupmeeste voorid uhke kaubaga, nahkade, puust ja savist nõude, rehade, vikatite ja kõikvõimalike põlluharija igapäevaeluks vajalike kohalike toodetega, kella üheksaks kattub kirikuesine plats laadatelkidega, kuhu asuvad müüjad uhke kauba ja igasugu pudipadiga. Nende vastas paiknevad kohalike toodete müüjate koormad. Kogu plats keeb rahvast ja mattub lärmakas kõnes: üks pakub osta rätte ja sitsi, teine nahka ja rehasid; too müüb vikateid, teine nuge ja kirveid, üks kaupleb märsimüüjaga, teine ostab vikativart; jõukur palub kaaluda puuda murakaid, vaene ostab soolakala. Ühesõnaga kõik ja igaüks on haaratud oma kauba ja toodete müümisest ja igaüks kiirustab midagi ostma, lugedes oma kohustuseks rõõmustada koduseid ja saabunud sugulasi ostudega kohalikul laadal" - nii näiteks kirjeldatakse prohvet Eelia püha Aunuse kubermangu Aunuse kreisi Iljinski vallas (Miroljubov 1872: 772).

Rahvakalendri sügis-talvisel perioodil, mis kestis Neitsi Maarja kaitse ja eestpalve pühast suure paastu alguseni, asendusid patroonipühade rahvapeod alati noorte kogunemistega mõnes asula taredest. Üksikutel juhtudel algasid istjad mõnes vene külas Jumalaema sünnipäevast, aga karjalastel ristiülendamise päevast. Äänisetaguses kandsid need nimetust бесёдьı, Puudožis вечёрки, Pomorjes вецерины, karjalastel beśśodat (Seesjärvi), beśodut (livvi), vepslastel besedad, besedsijad ("vestluskohad"), večera (Loginov 2008: 15-60; DKSK 1980: 98; Vinokurova 1996: 54). Vestlusõhtud toimusid tavaliselt raha eest kogu sügis-talveks renditud tares või järgemööda tüdrukute kodudes. Pidulike vestlusõhtutega kaasnes tants, laulud ja mängud, mis Karjalas eri külades varieerusid. Sel ajal töötamist peeti patuks.

Talviste patroonipühadega on põhjavepslastel ja karjalastel seotud tüdrukute, tavaliselt venna- või õetütarde pikaajaline sugulastel (kõige sagedamini emaliinis) külasviibimine, seda kutsuti adiv (põhjavepslased); ativo, adivo (päriskarjalased); ad'vo (livvi); adv , adiv (lüüdi) (DKSK 1980: 14; Vinokurova 1996: 65). Selle kombe kohaselt sõitis tüdrukute onu, tädi- või onupoeg patroonipüha eelõhtul läbi naaberasulad, kus ta nooremad sugulased elasid, ja kogus nad enda poole kaheks-kolmeks nädalaks külla. Kui külasviibimise aeg läbi sai, tuli tüdrukutele järele nende isa või vend, ja viis nad koju tagasi. Selline külaskäimine oli tüdruku elus suurepärane aeg, mille vältel ta osales guljanjetel, pidulikel ja argistel istjatel talle uues noorteseltskonnas, 
mis laiendas tulevase abikaasa valiku ringi. Samal ajal aitasid ühte majja kogunenud viis või rohkem tüdrukut perenaist mitmesugustes kergemates majapidamistöödes: pesid laupäeviti põrandaid, tõid puid ja vett. Raskemate töödega polnud kombeks neid koormata. Tüdrukute külaskäimise komme oli tuntud ka väljaspool Karjalat asuvates vepsa külades, kuid nendega seotud kindlaid ühiskondlikke norme, samuti eraldi nimetust, ei olnud kinnistatud. Nagu põhjavepslastel ja karjalastel, olid tüdrukute pühadeaegsed külaskäigud sugulaste juurde tuntud ka Äänisjärve-äärsete venelaste juures. J. Surhasko andmete kohaselt eksisteerisid abielulised sugulussidemed vene ja karjala külades (eriti Äänisjärve venelaste ja lüüdikute vahel) 20. sajandi 80. aastateni (Surhasko 1981). Paljudes teistes vene piirkondades toimus tüdrukute pühadeaegne külaskäimine kõige sagedamini sõpruse, mitte sugulussidemete alusel, seepärast sõitis tüdrukule teise külla järele ka kas tema sõbranna või eakaaslasest naissugulane, mitte meessugulane (Gromõko 1986: 239).

2. Külapühad Aunuse kubermangus. Iga suuremasse külastusse kuuluv küla tähistas lisaks kirikupühadele ka oma püha. Külapühad olid erinevat päritolu. Suur osa neist oli pühendatud mõnele pühakule või õigeusukiriku ajaloosündmusele, mille auks oli püstitatud küla-kabel. Nende pühade pidamisest karjalastel kirjutas anonüümne autor ajalehes Olonetskije Gubernskije Vedomosti järgmist: "Igas karjala külas, isegi kõige pisimas, rääkimata siis pogostist, on oma püha... Nii nagu igas külas (väheste eranditega) on kasvõi väike kabel, peetaksegi peamiselt nende pühakute ja tähtpäevade pühi, kelle auks on püstitatud kabel ja kelle ikoonid seal asuvad. Neid peamisi pühi kutsutakse "kabelipühadeks" (vene часовенныци, Р. M. 1894: 9). Kabelipüha stsenaariumisse kuulusid peaaegu samad elemendid, mis patroonipühade puhul: külaskäik, kabeli külastamine, liturgia, ristikäik, pidulõuna, guljanje külas, mängud. Ulatuselt ja pidulikkuselt jäi kabelipüha patroonipühale alla, see nägi välja nagu miniatuurne patroonipüha (MP 1883). Selle püha pikkus oli üldjuhul üks päev. Näiteks Šokša valda kuuluvates vepsa külades olid kabelipühad mihklipäev (8. novembril) Tšoga külas, kevadine ja sügisene jüripäev (23. aprill ja 26. november) Vassiljevskaja külas (Vinokurova 1996: 40). Kansaniemi valla vene elanikkond tähistas järgmisi kabelipühasid: ristiülendamise püha (сдвиженье) Kansaniemi külas, Tihvini Jumalaema ikooni päev (26. juuni, тихвинска) Varišpelda külas, suurmärter Demetriuse päev 
(26. oktoobril) Kolkosalma külas, Neitsi Maarja kaitse ja eestpalve püha (pokrov) Kolgsaari külas (Loginov 2005: 108).

3. Tõotuspühad, mille territoriaalne haare varieerus: külastu, külade rühm, küla. Kohalike pühade hulka kuulusid ka tõotuspühad (vene заветные, vepsa zavetan praznikad) või lubaduspühad (vene обетные праздники, livvi jiäksindähiine pruazńiekku, jiäksindö) (Vinokurova 1996: 110; SKJ 1990: 102). Neis mõnevõrra erinevates nimetustes kajastuvad nimetatud pühade eripärad: tõotuspüha kui minevikust päritud ja esivanemate käsul tähistatav püha; lubaduspüha - tekkinud lubaduse põhjal, mida tuleb tingimata täita. Tõotuspühi pidasid kohalikud elanikud nende endi poolt kohalikku elu mõjutanud erakordsetel asjaoludel antud tõotuse põhjal, ning püha tähistamise komme anti edasi põlvest põlve. Tõotuse andmise põhjuseks võis olla mingi kollektiivne häda - epideemia, karja hukk, tulekahju vms, mis õnnestus ära hoida või tagajärgi leevendada, pöördudes Jumala, Jumalaema või pühaku poole, kes sellest hetkest sai antud paiga kaitsjaks: Jumala armu märk oli "ikooni või kabeli ilmumine". Nii peetakse Undjärvi vallas esimesel pühapäeval pärast peetripäeva (29. juuli) Püha Kannataja Paraskeva auks. Kohalike elanike juttude kohaselt sai püha pidamise põhjuseks asjaolu, et "Püha Kannataja Paraskeva kabel ilmus sel päeval esimest korda valla inimestele". Sellest ajast peale "peetakse püha suure innu ja hardusega" (SP 1852: 1).

Valdav enamus Aunuse kubermangu tõotuspühadest tekkis seoses kunagise karjakaotusega ja nad torkavad silma eriliste rahvapäraste nimede poolest. Näiteks vepslastel nimetati neid pühasid živatan praznikad (karja pühad), lehmän praznikad (lehmapühad), hebon praznikad (hobusepühad). Mõne püha tekkest on säilinud pärimus. Ladva külastus näiteks pajatatakse märtrite Kerükuse ja Julitta tõotuspüha (15. juuli) tekke põhjustest järgmist: "Aastatel 1833-35 möllas Ladvas ja selle ümbruses Siberi katk, murdis mitte üksnes loomi, vaid ka inimesi. Kohalikud elanikud pöördusid sellest hädast pääsemiseks palvetega märtrite Kerükose ja Julitta poole, pidasid kabelis palvuse, kandsid püha vett piserdades ikooni ümber karja, mille peale katk taganes ega ole enam kordunud. Sellest ajast peale on kombeks pühitseda 15. juulit - pühade märtrite mälestuspäeva, ja sooritada ristikäik kohalikust Uspenski kirikust kabelisse, mida tänini ka tehakse" (Skazanie 1894: 9). Tõotuspüha tekkimine Aunuse kubermangu Koronenä vallas oli seotud selliste asjaoludega: "Ammusel ajal tabas sarvloomi ja teisi pudulojuseid taud. Oli see Siberi katk või 
mõni muu taud, pole teada, aga räägitakse, et karja jäi vähe järele, suur osa sellest lõppes. [---] Suurest osast karjast ilma jäänud talumehed kurvastasid, nutsid, aga selge, et muret murega ei vähenda, sellepärast otsustati ühisnõul, et edaspidiseks oma karja haiguste vastu kindlustada, korraldada kohalikus kabelis palvus, tuua paastuaja keeluvõid ja see kohapeal ära süüa, mitte kellelegi müüa. Seda kommet täidetakse rangelt ka tänapäeval, vaatamata selle ammususele, sest 80aastased vanakesed ei mäleta selle algust" (Pokrovski 1872: 170). Eeliapäeva reede tõotuspüha tekkimise põhjust Matvejanseĺga külastus mäletasid kohalikud elanikud (70aastased ja vanemad) hästi veel 1980. aastate lõpus: "Kunagi oli lehmadel verikusisus, ja suvi oli väga kuiv, ja nähtavasti oli selliseid aastaid mitu. Ja vaat inimesed käisid kirikus, palvetasid seal ja andsid tõotuse eeliapäeva reedel seda püha pühitseda ja käia mööda kabeleid" (Vinokurova 1996: 110).

"Tõotuste" pühitsemise kõrgaeg langes suvisele ajale. Suuremal osal neist oli kindel kuupäev korraldamiseks, aga tuli ette ka "libisevaid" pühapäevi, mille arvutamise lähtekohaks olid kirikukalendri tähtpäevad.

Tõotuspühade pidamine erines mõnevõrra patroonipühadest. Ühine oli neil ainult palvus, mõnikord ristikäik. Pidupäeval kogunesid lähikülade või üheainsa küla elanikud kiriku või kabeli juurde. Karja kaitsmise tõotuspühal aeti selle koha juurde palju kariloomi ja hobuseid. Seesjärvi karjalaste Šuvipeä külas loeti märtrite Floruse ja Lauruse päeva (Frolan proazńikka, 18./31. augustil) hobusepühaks (hebozien proaznikka). Sel päeval aeti varahommikul kabeli juurde palju hobuseid. Peremehed tulid pühale ratsa või vankritega naaberküladest Juustjärvist, Pühäniemist, Heinäjärvist, Tšopinast. Preester pidas püha puhul palvuse ja pühitses vett spetsiaalselt valmispandud nõudes. Mehed sõitsid preestrist mööda hobustel, keda too piserdas püha veega, sõnades: “Ole terve!” (DKSK 1980: 100-101). Suoju pogostis pühitseti märtrite Floruse ja Lauruse päeval samuti kabeli juures hobuseid (Nikitin 2004: 339). Erinevalt Karjala elanikkonnast (praegustes administratiivpiirides) olid kesk-ja lõunavepslastel hobustega seotud tõotuspühad (hebon praznikad) sageli ühitatud Makabei päevaga (1. august) ja sel puhul ujutati kohalikes veekogudes loomi. Et hobused oleksid terved, ratsutasid mehed nende seljas vette (Vinokurova 2007).

Äänisjärve vepsa aladel on fikseeritud kaks kariloomadega seotud tõotuspühade tähistamise viisi. Esimene, peaaegu samasugune nagu Seesjärvi karjalastel, oli iseloomulik Kaleigi, Kaskeza, Kukagdí ja 
Pervakoi asulatele: külaelanikud ajasid palvuseks kariloomad kohaliku kabeli juurde (Vinokurova 1996: 110).

Teine viis sisaldas lisaks palvusele ristikäiku. See oli levinud Matvejanseĺga külastus (eeliapäeva reedel), Vehkois (kasupüüdmatute imetegijate Kosmase ja Damianuse päev, 1. novembril), Šoutaŕves (ristikäik), Toižegis (Smolenski Jumalaema ikooni päev 28. juunil). Näiteks Toižegis käis vaimulik ristikäiguga jumalaema Smolenski pühakuju päeval järgemööda läbi kõik selle asuala külad, pidas iga külakabeli juures palvuse ja piserdas püha veega püha auks kokkuaetud karja. Šoutaŕve külastus kajastus selline tähistamise vorm ka püha rahvapärases nimetuses - ristikäik - kuigi selle ametlik nimetus oli Kaasani Jumalaema ikooni päev (8. juulil) (Vinokurova 1996: 110-111).

Tõotuspühade oluline osa oli lepitav või tänav veretu ohver Jumalale, Jumalaemale ja pühakutele. See kujutas endast ohverdamist pühas kohas. Ohvrianniks võisid olla käterätid, pearätid, kangatükid, küpsetised, munad, raha. Karjakaitse tõotuspühadel viidi kirikusse või kabelisse loomakasvatussaadusi - villa, võid, koort, piima, kohupiima. Näiteks Seesjärvi karjalased viisid peetripäeval Mahosoari saarele suurtes kogustes võid, pirukaid ja karjala pirukaid. Kabelisse jäetud toiduaineid kasutati kiriku hüvanguks (DKSK 1980: 93). Ühe Koronenä valla küla talupoegadel oli iidsetest aegadest komme "teisel ja sellele järgneval pühapäeval pärast peetripäeva tuua kohalikku kabelisse paastuajal keelatud võid" (Pokrovski 1872: 170).

Tõotuspühade külaskäikude iseärasused ja määr oli Aunuse kubermangus külati erinev. Äänisjärve vepslastel ei olnud kariloomade tõotuspühadel erinevate külade ja asulate elanike vastastikused külaskäigud kombeks. Elanikkond pidas sellest tavast rangelt kinni. Selles osas on näitlik O. Matvejeva (sünd 1913 Matvejanseĺga külastus) lugu. Tema vanaemal oli mittevepslasest väimees, kes tuli kaugelt Šoutaŕve külla kellassepaks ega tundnud kohalikke kombeid. Eeliapäeva reedel (kariloomade tõotuspühal) tuli ta Matvejanseĺga pühade puhul ämma külastama, aga too, muidu alati rõomsameelne perenaine, võttis teda vastu ilmse rahulolematusega ja ütles: "Ljova, see on ju lehmapüha" (Vinokurova 1996: 111). Aunuse kubermangu vene ja karjala külades tulid tõotuspühadele naaberkülade elanikud ja vaesed (DKSK 1980: 93). Külaskäikude haare oli väiksem kui patroonipühade puhul. Tüdrukute pikem külasviibimine oma sugulaste juures ei olnud tõotuspühade ajal levinud. Tõotuspühade külastamise eesmärk oli eelkõige osalemine lubaduse andmise religioossetes kombetalitustes, mitte suhtlemine sugulaste ja tuttavatega ning majast majja külaskäimine. 
4. Tõotus- ja patroonipühad loomohvri toomisega. Paljudes Karjala vene ja karjala külades tähistati tõotus- ja patroonipühi, mille osaks oli oinaste või härgade tapmine, pühendatuna kogukonna poolt tänutäheks pühakule tema eestkoste eest või abilootuses, ning ühised söömaajad. Nende pühade puhul segunesid paganlike ohverdamiste reliktid imekspandavalt õigeusu rituaalidega. Kõige sagedamini peeti neid peetripäeval, eeliapäeval, Neitsi Maarja taevasseminemise päeval või libisevalt pühapäeval pärast neid päevi. Näiteks nimetasid Seämärvi livvikud eeliapäevale järgneval pühapäeval peetavat tõotuspüha oinaspyhäpäivü (oinapühapäev) (Konkka 2008: 332). Suisaari külas tähistati eeliapäevale järgneval pühapäeval niinimetatud oinapühapäeva. Kohalikud elanikud ohverdasid prohvet Eeliale valgeid oinaid, et ta hoiaks karja haiguste ja nälja eest ega laseks kiskjaid ligi (Loginov 1997: 127-128). Lisaks kõigi ümbruskonna talupoegade ühisele palvele esitati pühakutele ka isiklikke lubadusi. Näiteks Äänisetaguses "annab taluperemees mingi loomakasvatuse õnneliku või õnnetu juhtumisega seoses lubaduse (rahvapäraselt завечает tõotab) tuua prohvet Eeliale, kelle auks on nimetatud selles asulas kirik või kabel, ohvriks oma karjast oina või lamba. Kui talumehe karjast kaob lammas või oinas, annab peremees samuti tõotuse: kui lammas üles leitakse, ohverdab ta selle prohvet Eeliale. Mõnikord koguneb aastaga selliseid ühel või teisel asjaolul antud ohverduslubadusi palju, ning kombekohaselt siirduvad külas eriti auväärsed vanamehed esimesel pühapäeval pärast 20. juulil peetavat prohvet Eelia püha ringkäigule majast majja ning koguvad kokku lubatud lambad ja oinad, aga nende keetmise lisandiks kruupe ja soola" (NO 1887: 231). Mõnikord lubati tuua oinas (härg) ohvriks sellele pühakule, kelle auks oli rajatud pühakoda või mõni selle altar.

Loomade ohverdamisega pühade läbiviimise skeem oli peaaegu kõikjal ühesugune. Pidupäeval ajasid ühe või mitme küla elanikud ära lubatud oinad või härjad kabeli või kiriku juurde. Kuni toimus jumalateenistus, toimetati ka loomade tapmine, lihakehade tükeldamine ja liha keetmine kateldes. Pärast jumalateenistust korraldati kiriku või kabeli läheduses söömaaeg, mille käigus kõik kogukonnaliikmed jõid koos leent ja sõid liha. Pealtnägija I. Smirnovi andmetel toimus näiteks Taržala külas 1872. aastal prohvet Eeliale pühendatud tõotuspüha järgmiselt: "Kell 9 hommikul hakkasid kellad palvusele kutsuma, ja erivärviliselt riietatud rahvasummad venisid kiriku poole, oli sissesõitnud külalisi ja kohalikke elanikke. Sel ajal, kui kirikus käis teenistus, mässas salk talupoegi pühakoja lähedal suure katla ümber, mille alla 
oli tehtud tuli; siin ka tapeti ja nüliti äralubatud loomi - lammast ja lehma, nende suurteks tükkideks tehtud liha pandi katlasse. Pärast teenistust, mille ajal vaimulik oli pidanud jutluse prohvet Eelia elust ja tegudest, suundus rahvas sinna, kus valmistati ette tõotuspüha söömaaega. Aasale olid pandud lauad, kuhu oli asetatud juba keedetud liha. Tuli preester kaaskonnaga, õnnistas söömaaja ja proovis liha..." (Smirnov 1872: 1011). 19. sajandi lõpus tõid kaubalis-rahalised suhted pidutsemisse muutusi. Aunuse kubermangu Vieljärvi vallas näiteks toodi eeliapäevaks mitu härga. Aga siin neid ei keedetud. Tavaliselt tapeti üks härgadest teisel päeval, liha jagati kirikuteenijate vahel, aga teised härjad müüdi maha ning raha laekus kirikule. (P. M. 1891: 611).

Aunuse kubermangus elavatel vepslastel oli härgade ja lammaste vereohver pühade ajal levinud üksnes Võtegra kreisi Särgóäŕve vallas, samuti naabruses asuvas Novgorodi kubermangu Belozerski kreisi Markovo kihelkonna Kuja ja Pondala vallas (Vinokurova 1989: 127-128). Nende korraldamisaeg oli viidud kooskõlla kolme daatumiga - kristlike pühakute prohvet Eelia, apostlite Peetri ja Pauli või Jumalaema mälestuspühaga. Oina või talle (härja ja mullika kõrval) ohverdamist peeti kohustuslikuks, muidu kohalike elanike arvates "söövad hundid meie karja ära ja me jääme karjast ilma", "kogu vili kuivab ära, põleb põllul". Nendes interpretatsioonides kajastub ohverdamise funktsioon põllumajanduses ja karjakasvatuses: kaitsta karja ja vilja. Kombekohaselt toimus tapmine äärmiselt julmal viisil: “Tuuakse (kabelisse) tall, härg, mullikas, kõik tapeti kivilöögiga otsaette, mitte kirvega vaid kiviga. Aga kui tal (loomal) lõigati kõri lõhki, siis mitte noaga, vaid rebiti kõri naelaga" (Zaitseva \& Mullonen 1969: 74-75). Veel üksikasjalikum selle püha kirjeldus Säŕgǵäŕves leidub A. Svetljaki materjalides: "Varasest hommikust ajavad mitu perenaist oma lammaste seast lubatud loomad pogosti prohvet Eelia kabeli juurde. Siin löövad nad oma loomad kividega maha ja siinsamas, kirikuaia lähedal puhastavad ja keedavad liha suurtes kateldes. Soolikaid, sisikonda ja rupskeid ei tohi keegi võtta, need visatakse järve. Kuni kirikus käib teenistus, jõuab ohvriloomade liha pehmeks keeda. Pärast teenistust tuleb kogu rahvas eesotsas vaimulikuga ristikäigus kellade helina saatel kabeli juurde. Alguses loetakse palve prohvetile, seejärel asutakse ohvrisöömaaja kallale, kusjuures igaüks saab ohvrist oma osa" (Svetljak, Vene Geograafiaühing p 119, kirje 1, nr 343). 
Loomade ohverdamisega seotud tõotuspühad venelastel, karjalastel ja vepslastel (Aunuse kubermang ja ümberkaudsed alad)

\begin{tabular}{|c|c|c|}
\hline Asustuspunkt & Pühitsemise päev & Pühitsemise keskus \\
\hline $\begin{array}{l}\text { Vieljärvi vald } \\
\text { (Aunuse kreis) }\end{array}$ & Eeliapäev (20.07) & \\
\hline $\begin{array}{l}\text { Viidana vald } \\
\text { (Petroskoi kreis) }\end{array}$ & Eeliapäev & $\begin{array}{l}\text { Püha Imetegija Nikolai } \\
\text { kabel }\end{array}$ \\
\hline $\begin{array}{l}\text { Vuokkiniemi vald } \\
\text { Venehjärvi küla } \\
\text { Jyvöälahti küla }\end{array}$ & $\begin{array}{l}\text { Eeliapäev } \\
\text { Neitsi Maarja } \\
\text { taevasseminemise päev } \\
(15.08) \\
\text { Pokrov }(01.10)\end{array}$ & $\begin{array}{l}\text { Eelia kirik } \\
\text { Kabel } \\
\text { Kuittijärve kabel }\end{array}$ \\
\hline $\begin{array}{l}\text { Kansaniemi vald } \\
\text { Iljinski pogost }\end{array}$ & Eeliapäev & Prohvet Eelia kirik \\
\hline Kansaniemi küla & Peetripäev (29.06) & \\
\hline $\begin{array}{l}\text { Kenjärvi vald } \\
\text { (külanimi teadmata) }\end{array}$ & Oinapäev (juulis) & \\
\hline Korpijärvi vald & Eeliapäev & \\
\hline $\begin{array}{l}\text { Kuganavoloki vald } \\
\text { Pretšistinski pogost }\end{array}$ & Peetripäev & \\
\hline Kupetski vald & $\begin{array}{l}\text { Püha Makariuse päev } \\
(26.07)\end{array}$ & $\begin{array}{l}\text { Püha Makariuse kabel } \\
\text { Kupetski järvel }\end{array}$ \\
\hline $\begin{array}{l}\text { Ladva vald } \\
\text { (Petroskoi kreis) }\end{array}$ & Eeliapäev & \\
\hline $\begin{array}{l}\text { Laajajärvi } \\
\text { Kaškana }\end{array}$ & Eeliapäev (härjapäev) & \\
\hline Lugovskoi vald & $\begin{array}{l}\text { Peetripäeva järgne } \\
\text { pühapäev }\end{array}$ & \\
\hline $\begin{array}{l}\text { Maaselkä-Poadene } \\
\text { vald } \\
\text { (Poventsa kreis) } \\
\text { Selgi küla }\end{array}$ & $\begin{array}{l}\text { Neitsi Maarja } \\
\text { taevasseminemise päev }\end{array}$ & $\begin{array}{l}\text { Uspenski kabel } \\
\text { Mahosoarel }\end{array}$ \\
\hline $\begin{array}{l}\text { Munjärvi vald } \\
\text { (Petroskoi kreis) } \\
\text { Bošinkülä } \\
\text { Uíkoise küla } \\
\text { Nimjärvi küla }\end{array}$ & $\begin{array}{l}\text { Jüripäev (23.04, } \\
\text { oinapäev) } \\
\text { Eeliapäev (oinapäev) } \\
\text { Eeliapäev (oinapäev) } \\
\text { Smolenski Jumalaema } \\
\text { ikooni päev } 28.06 \\
\text { (oinapäev) }\end{array}$ & \\
\hline
\end{tabular}




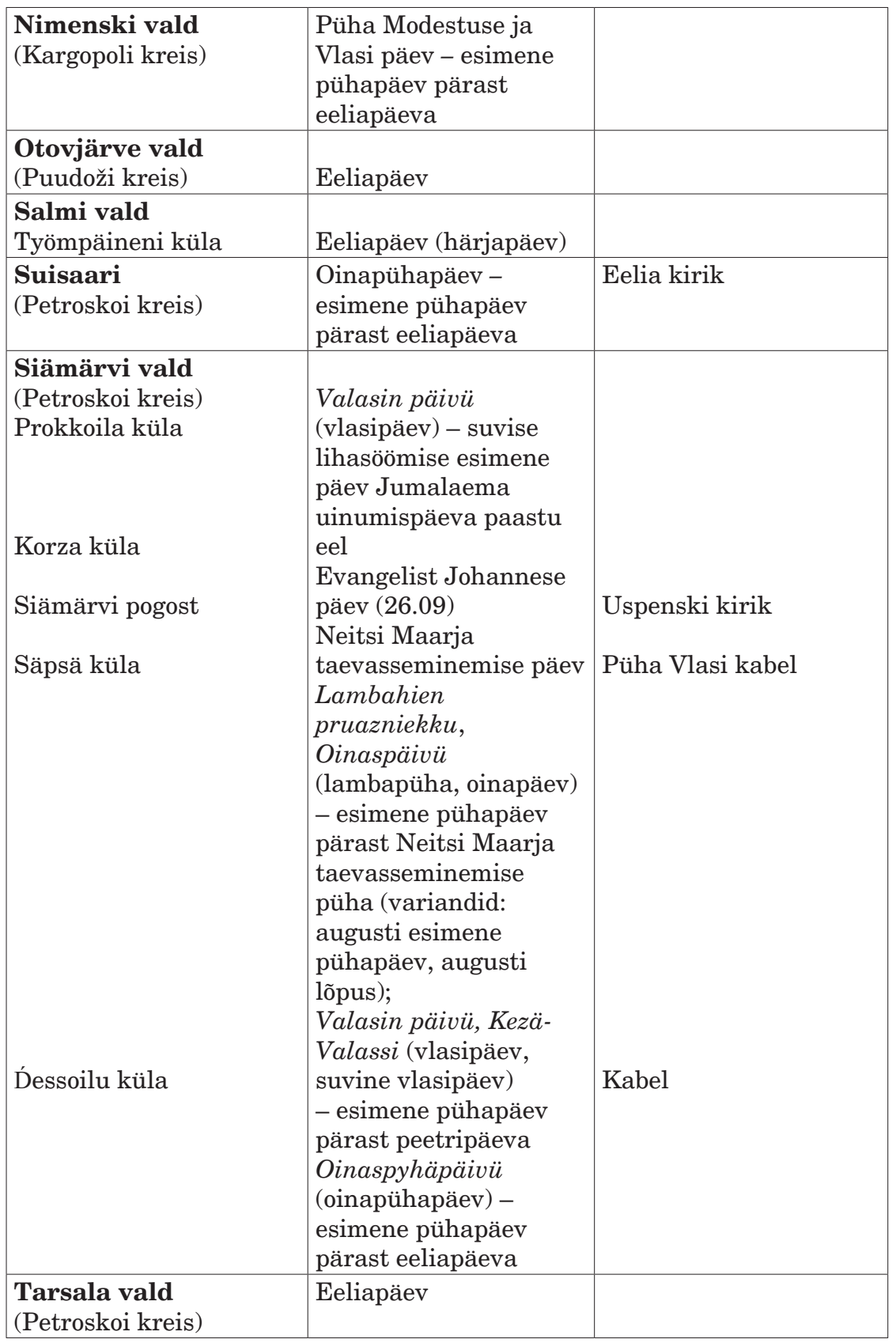




\begin{tabular}{|l|l|l|}
\hline $\begin{array}{l}\text { Šiltja vald } \\
\text { (Võtegra kreis) }\end{array}$ & $\begin{array}{l}\text { Härjapäev, tähistati: } \\
\text { 1) eeliapäeval, kui see } \\
\text { langes pühapäevale või } \\
\text { 2) esimesel pühapäeval } \\
\text { pärast eeliapäeva }\end{array}$ & Prohvet Eelia kirik \\
\hline $\begin{array}{l}\text { Šuoju vald } \\
\text { (Petroskoi kreis) } \\
\text { Plaksino küla }\end{array}$ & $\begin{array}{l}\text { Oinapühapäev - } \\
\text { esimene pühapäev } \\
\text { pärast eeliapäeva }\end{array}$ & Kabel saarel \\
\hline $\begin{array}{l}\text { Jänispelto külastu } \\
\text { Katšena küla } \\
\text { Tullahti küla }\end{array}$ & $\begin{array}{l}\text { Oinapühapäev } \\
\text { Oinapühapäev }\end{array}$ & $\begin{array}{l}\text { Kabel } \\
\text { Kabel }\end{array}$ \\
\hline
\end{tabular}

Kuja ja Voilahti külastute külades korraldati kollektiivseid loomade ohverdamistega söömaaegu sügissuvisel ajal kaks korda: esimesel pühapäeval pärast peetripäeva ja esimesel pühapäeval pärast Neitsi Maarja taevasseminemise päeva. Neid pühasid nimetati vastavalt toimumiskohale peń slabad (väike-sloboda) ja suŕ slabad (suur-sloboda) - üksiktaludega asustatud Slobodi külas, kus asus ka Korsuni Jumalaema ikooni (9. oktoober) kirik. Mõnikord nimetati neid pühasid ka kiriku rahvapärase nime (Koršunskaja) järgi väike ja suur koršunskaja. Sõnadega "väike" ja "suur" rõhutati püha tähtsust, mis ilmnes selle korraldamise vormis. Väikesele slobodale (peń slabad) oli kombeks minna jala, suurele (suŕ slabad) sõideti tingimata hobustega.

Kogu kogutud informatsioon ${ }^{4}$ loomade ohverdamisega seotud pühade levikust Aunuse kubermangus ja osaliselt selle lähialadel on paigutanud tabelisse.

Loomade ohverdamisega seotud pühadel kostitati külalisi nii ühissöömingutel kui ka eraldi taludes.

Antud teema nõuab jätkamist. Aunuse kubermangu ja selle lähialade pühade klassifitseerimise järgmine etapp on mõeldamatu ilma üksikasjalike küsitlusteta välitöödel, selgitamaks asulate kaupa välja nende pühad, pühade rahvapärase määratluse, nende tekkepõhjused, tähistamise skeemi ja külaskäimise ulatuse. Kõigile neile küsimustele ei ole hetkel käsutuses olevate allikate põhjal alati veel võimalik vastust leida.

Vene keelest tõlkinud Asta Niinemets 
Originaal: Винокурова И. Ю. 2010: Праздничная система крестьянского населения Олонецкой губернии (конец XIX начало XX в.). Праздничные традиции и новации народов Карелии и сопредельных территорий: исследования, источники, историографбия. Петрозаводск: Карельский научный центр РАН, lk 9-37.

\section{Kommentaarid}

1 Käesoleva artikli tõlkes on kohanimede puhul kasutatud eelistatult läänemeresoome (karjala, vepsa, ka soome) teadaolevaid nimevariante vene omade asemel.

2 Vene часовенские, nimetus võib, aga ei tarvitse olla seotud kabeliga (часовня). See võib ennem olla seotud õigeusu praktikaga lugeda palveid ööpäeva kindlatel aegadel (vene чumamb часы) - toim.

3 Kõik kuupäevad on toodud vana kalendri järgi. Vana ja uue kalendri vahe on 13 päeva.

4 Vt kirjanduse loetelu artikli lõpus.

\section{Arhiivimaterjalid}

NSVL TA NSV rahvaste uurimise instituut. Teaduste Akadeemia arhiiv, f 135.

Svetljak (Fomin), A. V. Vepsa lugudest: nõiasõnad ja lausumised, välja kirjutatud Lodeinoje Pole end Šimǵäre valla vepsa talupoja märkmevihikust 1926-1933. Vene Geograafiaühing p 119, kirje 1, nr 343.

J. Perttola materjalid Soome Kirjanduse Seltsi (SKS) rahvaluule arhiivis, nimele järgneb teksti arhiivinumber. 


\section{Kirjandus}

Beloussov 1974 = Белоусов, Я. П. Праздники старые и новье (некоторые философские аспекты проблемы празднования). Алма-Ата: Казахстан.

Bernštam 1988 = Бернштам, Т. А. Молодежь в обрядовой жизни русской общины XIX - начала XX в. Ленинград: Наука.

Bernštam 2009 = Бернштам, Т. А. Народная культура Полорья. Москва: ОГИ.

FRS 1975 = Вахрос, И. \& Щербаков, А. (koost). Финско-русский словарь Suomalais-venäläinen sanakirja. Москва: Русский язык.

Gromõko 1986 = Громыко, М. М. Традиционные норлы поведения и фборль общения русских крестьян XIX в. Москва: Наука.

DKSK 1980 = Конкка, У. С. \& Конкка, А. П. (koost). Духовная культура сегозерских карел конца XIX - начала XX в. Ленинград: Наука.

Konkka 1988 = Конкка, А. П. Жертвоприношения животных на летних календарных праздниках карел (материалы к описанию обряда). Обряды и верования народов Карелии. Петрозаводск: Карельский филиал АН СССР, lk 77-95.

Konkka 2008 = Конкка, А. П. Календарная мифология и обрядность сямозерских карел. История и культура Сямозерья. Петрозаводск: Издательство Петрозаводского государственного университета, lk 301-347.

К. Р. 1883 = К. П. Деревянное. Олонеикие губернские ведолости 63, lk 646.

Kulikovski 1888 = Куликовский, Г. И. Иванов день в селении Кузаранде, Петрозаводского уезда. Олонеикие губернские ведомости 54, lk 515-517.

Kulikovski 1895 = Куликовский, Г. И. “Общественный пир” в Каргопольском уезде. Олонецкие губернские ведолости 9, lk 5-6.

Loginov 1993 = Логинов, К. К. Материальная культура и производственнобытовая магия русских Заонежья (конеи XIX - начало XX в.). СанктПетербург: Карельский научный центр РАН.

Loginov 1997 = Логинов, К. К. Этнографическое описание села Суйсарь. Гришина, И. Е. \& Краснопольская, Т. В. \& Логинов, К. К. (koost). Село Суйсарь: история, быт, культура. Петрозаводск: Издательство Петрозаводского государственного университета, lk 15-60. 
Loginov 2005 = Логинов, К. К. Система традиционных праздников Водлозерья. Структура и диналика природньх әкосистем и фбормирование народной культуры на территории национального парка “Водлозерский”. Матер. отчет. конф. о научн. деят. НП “Водлозерский” по итогам 2002-2004 гг., 17.02.2005 г. Петрозаводск: Карельский научный центр PAH, lk 106-111.

Loginov 2008 = Логинов, К. К. Народный календарь и праздники народов Карелии. Мальми, В. Г. \& Логинов, К. К. (koost). Слово и праздник. Петрозаводск: Карелия, lk 15-60.

Miroljubov 1872 = Миролюбов. Праздник в честь пророка Илии в селе Ильинском (Олонецкого уезда). Олонецкие губернские ведомости 67, lk 772-773.

MP 1883 = Местный праздник в селе Обжи, Олонецкого уезда и освящение часовни (Корреспонденция Губ. Вед.). Олонецкие губернские ведолости 47, lk 484-485.

Nikitin 2004 = Никитин, Г. А. Жертвоприношения в Карелии (публикация O.М. Фишман). Материалы по этнографбии II. Народы Прибалтики, Северо-Запада, Среднего Поволжья и Приуралья. Санкт-Петербург: Российский Этнографический музей, lk 335-347.

Nikolskaja 1981 = Никольская, Р. Ф. Пища и кухонная утварь. Материальная культура и декоративно-прикладное искусство сегозерских карел. Ленинград: Наука, lk 138-178.

Nimenski 1873 = Нименский, В. Ильин день в Шильде. Олонецкие губернские ведомости 64, lk 745-746.

NO 1887 = Народный обычай. Олонецкие губернские ведомости 29, lk 231.

Pimenov 1964 = Пименов, В. В. К истории сложения типов поселений в Карелии. Советская этнографбия, lk 3-18.

Р. М 1891 = П. М. Ильин день в селении Виданы (Петрозаводского уезда). Олонецкие губернские ведомости 60, lk 610-611.

Pokrovski 1872 = Покровский, П. Обычай есть скоромное масло у часовни (Письмо в редакцию Олон. губ. вед.). Олонеикие губернские ведомости 14, lk 170-171. 
Pokrovskaja 1974 = Покровская, И. П. Население дореволюционной Карелии по материалам переписи 1897 г. Кяйвяряйнен, И. И. (toim). Вопросы истории Европейского Севера. Межвуз. науч. сб. Петрозаводск: Издательство Петрозаводского государственного университета, lk 91-118.

Polištšuk 1997 = Полищук, Н. С. Развитие русских праздников. Александров, В. А. (toim). Русские. Москва: Наука, lk 573-601.

Sarmela, Matti 1969. Reciprocity systems of the rural society in the FinnishKarelian culture area with special reference to social intercourse of the youth. Folklore Fellows' Communications 207. Helsinki: Academia Scientiarum Fennica.

SKJ 1990 = Макаров, Г. Н. (koost). Словарь карельского языка. Петрозаводск: Карелия.

Smirnov 1872 = Смирнов, И. Ильинский праздник в селе Таржеполь (Петрозаводского у.). Олонецкие губернские ведолости 88, lk 1010-1011.

SOSDKVSJ 2007 = Сопоставительно-ономасиологический словарь диалектов карельского, вепсского, саалского языков. Петрозаводск: Карельский научный центр РАН.

SP 1852 = Сельский праздник. Олонеикие губернские ведомости 39.

Surhasko 1977 = Сурхаско, Ю. Ю. Карельская свадебная обрядность (конец XIX - начало XX в.). Ленинград: Наука.

Surhasko 1981 = Сурхаско, Ю. Ю. О русско-карельском этнокультурном взаимодействии (по материалам свадебной обрядности конца XIX начала XX в.). Русский Север. Проблемы этнографии и фольклора. Ленинград.

Zaitseva \& Mullonen 1969 = Зайцева, М. И. \&, Муллонен, М. И. Образиы вепсской речи. Ленинград: Наука.

Zaitseva \& Mullonen 1972 = Зайцева, М. И. \& Муллонен, М. И. Словарь вепсского языка. Ленинград: Наука.

Żygulski 1985 = Жигульский, К. Праздник и культура. Праздники старые и новые. Разлышления социолога. Москва: Прогресс.

Toporov 1997 = Топоров, В. Праздник. Мифбы народов мира 2. Энциклопедия в 2-х тт. Москва: Науч. изд-во. 
Vinokurova 1989 = Винокурова, И. Ю. Вепсские заветные праздники охраны скота. Пименов, В. В. (vast. toim). Проблель истории и культурь вепсской народности. Петрозаводск: Карельский филиал АН СССР, lk 119-130.

Vinokurova 1994 = Винокурова, И. Ю. Календарные обычаи, обряды и праздники вепсов (конеи XIX-начало XX в.). Санкт-Петербург: Наука.

Vinokurova 1996 = Винокурова, И. Ю. Традиционнье праздники вепсов Прионежья (конеи XIX - начало XX в.). Петрозаводск: Издательство Петрозаводского государственного университета.

Vinokurova 2007 = Винокурова, И. Ю. Традиционные праздники вепсской деревни на рубеже XX-XXI вв. Вепсы и этнокультурные перелены XX века. Семинар в Санкт-Петербурге 5-6 октября 2006 г. Studia Slavica Finlandensia. Tomus XXIV. Хельсинки: Institute for Russian and East European Studies, lk 187-209.

\section{Summary}

\section{Peasant holiday cycle in Aunuse Province in the late 19th and early 20 th centuries}

\section{Irina Vinokurova}

Keywords: Olonets province, heritage culture, peasant holidays, Vepsian

When a researcher studies different holidays across a certain territory, the first thing he encounters is the systematisation and classification of holidays. This article is an attempt to answer the question about the main categories of holidays in the villages of Olonets province at the end of the 19th and beginning of the 20th centuries, when heritage culture remained rather stable.

The researcher encounters certain difficulties while reconstructing the traditional holiday cycle of the period under study in this province. One of them is the quality of source materials. Not all the settlements with their holidays are represented, and, besides, many of these settlements have disappeared by today or changed their names. Another problem is related to the multiethnicity of the population that inhabits the territory of the province, which has exerted influence on the holiday cycle. 


\section{Uurimusi vepsa rahvausust}

Koostaja ja toimetaja Madis Arukask

http://www.folklore.ee/rl/pubte/ee/sator/sator16/

ISSN 1736-0323 (veebiväljaanne)

ISBN 978-9949-544-96-7 (veebiväljaanne)

ISSN 1404-2011 (trükis)

ISBN 978-9949-544-95-0 (trükis)

DOI: 10.7592/Sator.2016.16

Tartu 2016

Sarja toimetaja: Mare Kõiva

Koostaja ja toimetaja: Madis Arukask

Keeletoimetaja: Asta Niinemets

Kaas ja kujundus: Andres Kuperjanov

Kaanefoto: Madis Arukask

Küljendus: Diana Kahre

HTML: Diana Kahre

Trükis ilmunud: Uurimusi vepsa rahvausust.

Koostaja ja toimetaja Madis Arukask. SATOR 16. Tartu 2016

Raamatu ettevalmistamist ja väljaandmist on toetanud Eesti Teadusagentuur (grandid nr 7385 ja 9271) ning Eesti Vabariigi Haridus- ja Teadusministeerium (projekt IUT 2-43). Raamatu toimetamist ja vormindamist toetas Euroopa Liit Euroopa Regionaalarengu Fondi kaudu (Eesti-uuringute Tippkeskus), see on seotud Eesti Teadusagentuuri institutsionaalse uurimisprojektiga IUT 22-5. Trükitud Eesti Kultuurkapitali toetusel.

E-raamatu valmimist toetas: EKKM14-344 Eesti keele, kultuuri ja folkloori kasutusalade laiendamine ja tutvustamine elektroonilistel infokandjatel.

(C) 2016 EKM Teaduskirjastus

(C) 2016 Eesti Folkloori Instituut

() 2016 EKM FO rahvausundi ja meedia töörühm

(C) 2016 autorid 